\title{
Triazines in the Tropical Lagoon System of Mundaú-Manguaba, NE-Brazil
}

\author{
Débora A. Azevedo, ${ }^{*, a}$ Thaís R. Silva, ${ }^{a}$ Bastiaan A. Knoppers ${ }^{b}$ and Detlef Schulz-Bull ${ }^{c}$ \\ ${ }^{a}$ Departamento de Química Orgânica, Instituto de Química, Universidade Federal do \\ Rio de Janeiro, Av. Athos da Silveira Ramos 149, 21941-909 Rio de Janeiro-RJ, Brazil \\ ${ }^{b}$ Departamento de Geoquímica, Universidade Federal Fluminense, Outeiro de São João Batista s/n, \\ Centro, 24020-141 Niterói-RJ, Brazil \\ 'Department of Marine Chemistry, Institute for Baltic Sea Research-Warnemünde, \\ University of Rostock, Seestrasse 15, D-18119 Rostok-Warnemünde, Germany
}

Triazinas foram analisadas no sistema tropical estuarino lagunar de Mundaú-Manguaba (MMELS), Estado de Alagoas, NE-Brasil, impactado pela monocultura de cana-de açúcar na sua bacia de drenagem. Amostras de água e sedimento foram coletadas em agosto/2006 (estação chuvosa) e fevereiro/2008 (estação seca da colheita) para determinação das triazinas: atrazina, simazina, desetilatrazina, desisopropilatrazina e desetil-desisopropilatrazina na fase dissolvida, no material particulado em suspensão e no sedimento de superfície. Amostras de água foram filtradas e após procedimento analítico, os extratos obtidos foram analisados por cromatografia gasosa acoplada a espectrometria de massas (CG-EM). O método de análise para as triazinas em material particulado foi avaliado, obtendo recuperações entre $72-123 \%$, desvios padrão relativo de 4,2-22 \% e limites de detecção de 0,2-0,3 $\mathrm{ng} \mathrm{L}^{-1}$. Sedimentos fortificados a 10, 20 e $50 \mathrm{ng} \mathrm{g}^{-1}$ foram extraídos em sistema de extração acelerada por solvente (ASE) e as recuperações foram de $68-133 \%$, desvio padrão relativo de 2-34 \% e o limite de detecção de 0,6-1,2 ng g $^{-1}$. Somente a atrazina foi detectada e em amostras de material particulado em suspensão durante a estação chuvosa em quatro pontos. As concentrações determinadas foram 3,1, 2,7, 1,6 e 0,7 ng L ${ }^{-1}$. Estes resultados sugerem que as triazinas são amplamente retidas e transformadas e/ou estejam sendo diluídas nas águas e degradadas devido ao metabolismo intenso no MMELS.

This study addresses triazines in the tropical and eutrophic Mundaú-Manguaba estuarine-lagoon system (MMELS) located in the State of Alagoas, NE-Brazil, affected by sugar-cane monoculture in its lower drainage basin. Water and sediment samples from MMELS were collected during the wet post-harvest season (August/2006) and the dry harvest season (February/2008). Trace analysis of the triazines atrazine, simazine, deethylatrazine, deisopropylatrazine and deethyldeisopropylatrazine were performed in surface sediments, suspended particulate matter and in the dissolved fraction in water. Water samples were filtered and after the analytical procedures, the resulting extracts were analyzed by gas chromatography-mass spectrometry. Additionally, the analytical method for suspended particulate matter was evaluated, the recovery being between 72-123\% with relative standard deviations of 4.2-22\% and limits of detection around 0.2-0.3 ng L-1. Sediments fortified at 10, 20 and $50 \mathrm{ng} \mathrm{g}^{-1}$ were extracted with the ASE system and recovery experiments lied between $68-133 \%$ with relative standard deviations of 2-34\%. The limits of detection were of 0.6-1.2 $\mathrm{ng} \mathrm{g}^{-1}$. Atrazine was the sole triazine detected and only in suspended particulate matter during the wet season at four sites, with low concentrations of 3.1, 2.7, 1.6 and $0.7 \mathrm{ng} \mathrm{L}^{-1}$. This suggests that triazines are either largely retained and transformed within the sugar-cane fields and/or are readily diluted in the waters and degraded due to the intense metabolism of MMELS.

Keywords: triazines, gas chromatography-mass spectrometry, water, suspended matter, sediments, estuarine-lagoon

*e-mail: debora@iq.ufrj.br 


\section{Introduction}

Tropical countries like Brazil, developed extensive monoculture practices with state-of-the-art plantation and harvesting technologies, including those for sugarcane (Saccharum officinarum L.). Since the Alcohol Program was launched in 1976 for vehicle fuel production, Brazilian agri-business now owns 7 million hectares or about $25 \%$ of the global sugar cane areas and is the major sugar cane producer in the world. The industry today, crushes 480 million metric tons of sugar cane, with $45 \%$ used to produce sugar and 55\% to produce alcohol. The demand is increasing on a national and international level and the potential for expansion is large. ${ }^{1,2}$ The Northeast and East coastal zone of Brazil accounts for $30 \%$ of the sugar cane production. With the increasing demand, pollution impacts of sugarcane practices upon estuaries and coastal waters are thought to be enhanced, with implications upon the water quality, fisheries yields, tourism and the socio-economic scenario as a whole. The lack of a multi-interdisciplinary scientific approach, as well as, the lack of a strict legislative control of the agribusiness, hampers the elaboration of adequate mitigation and management strategies for the sustainable development of the coastal realm.

Especially in tropical regions, agricultural intensification has led to a higher consumption of pesticides ${ }^{3}$ leading to a growing concern about possible environmental contamination from agrochemicals. Studies on pesticide occurrence in environmental samples from the tropics are increasing ${ }^{4-7}$ but still focus mainly on organochlorine pesticides, ${ }^{8}$ which have been banned in most countries during the last decades. ${ }^{4}$ As air and soil temperatures are higher in tropical than in temperate regions, an increased pesticide loss to the atmosphere by volatilization has to be expected, ${ }^{4}$ as well as by biodegradation.

The s-triazines are used worldwide as selective pre- and post-emergence herbicides for the control of weeds in many agricultural crops like corn, wheat, maize and barley. ${ }^{9}$ Due to their extensive use, high persistence, water solubility and relatively weak adsortivity they contaminate the aquatic environment by agricultural run-off, industrial sources, sewage discharge, and atmospheric input, and are therefore frequently detected in ground and surface waters. ${ }^{10}$ The main degradation products in ground and surface waters are dealkylated chloro metabolites, predominantly deethylatrazine (DEA) and deisopropylatrazine (DIA).

Atrazine shows higher acute toxicity than simazine, but in general concentration levels of both herbicides are rather low. However, besides the acute effects, the exposure to atrazine and simazine is suspected to have a long-term influence on the development, reproduction and health of several species. In particular the endocrine disrupting effects of the herbicides were extensively studied in recent years. In frogs, concentrations above $0.1 \mu \mathrm{g} \mathrm{L}^{-1}$ of atrazine were observed to induce retarded gonadal development and hermaphrodism. ${ }^{11}$

Atrazine is one of the most widely applied herbicides in the world. The global consumption is estimated at 70,000 $\mathrm{t}$ per year. The United States of America is the main consumer of atrazine, with an average consumption of 35,000 t per year, with about $75 \%$ of the corn, $75 \%$ of the sugar cane and $60 \%$ of the sorghum crops being regularly treated with atrazine. ${ }^{12}$ On corn and sorghum crops the herbicide is usually applied before the emergence of the crop, but post emergence application is also sometimes the case. Sugar cane crops are treated with atrazine during the planting stage and further applications after the emergence and at canopy closure may also occur. ${ }^{12}$ Simazine is less frequently used than atrazine. The estimated yearly consumption in the United States of America amounts to 3,000 t, about one tenth of the atrazine consumption. Main applications include the control of broadleaf and grassy weeds in fruit, nut, corn and sugar-cane crops and in forestry. Similar to atrazine, simazine is mostly applied at the planting stage, prior to the emergence of the weeds. Besides its agricultural application, it is also used for nonselective weed control e.g. on industrial sites, highways or railroads. ${ }^{13}$

In the European Union the residues of single herbicides in drinking water are limited to $0.1 \mu \mathrm{g} \mathrm{L} \mathrm{L}^{-1}$ and the critical value for the sum of herbicide residues is $0.5 \mu \mathrm{g} \mathrm{L}^{-1}$ (EU98/83/EG, 1998). In 2001, atrazine and simazine were included in the list of priority hazardous substances of the European Commission (EC) water framework directive (2000/60/EC, 2000; 2455/2001/ EC, 2001). Since the herbicides are suspected to have long term ecotoxicological effects and drinking water contamination beyond the given limits were frequently and ubiquitously observed, the European Union banned atrazine and simazine in September 2004. ${ }^{14,15}$ For surface waters, in 2006 the EC proposed environmental quality standards of less than $600 \mathrm{ng} \mathrm{L}^{-1}$ of atrazine and $1 \mu \mathrm{g} \mathrm{L}^{-1}$ of simazine as annual average concentrations. ${ }^{16}$ The recommended maximum allowable concentrations amount to $2 \mu \mathrm{g} \mathrm{L}^{-1}$ of atrazine and to $4 \mu \mathrm{g} \mathrm{L}^{-1}$ of simazine. However, in most countries outside the European Union, atrazine and simazine are still frequently and widely used. In the United States of America for instance, the Environmental Protection Agency (EPA) revised the risk assessment for atrazine and simazine and finally approved the further use of the herbicides in 2006. In drinking water, the concentrations of atrazine and simazine are limited to 3 and $4 \mu \mathrm{g} \mathrm{L}^{-1}$, respectively. ${ }^{12,13}$ 
In Brazil, the herbicide consumption in 2000 was approximately $82,000 \mathrm{t}$, with the northeast region corresponding to $6.3 \%$ of the national consumption. Their application is mainly concentrated in the agricultural areas, particularly in the sugar-cane crops. The total consumption of atrazine was about 10,000 t, ranking third among the ten most consumed pesticides of the country. ${ }^{17}$

The aim of this study was to analyze the herbicides atrazine, simazine and their metabolities in the dissolved fraction and suspended particulate matter in water and surface sediment samples of the tropical MundaúManguaba estuarine-lagoon system (MMELS) located in the State of Alagoas, NE-Brazil, impacted by sugar-cane monoculture practices over the last decades. Until the beginning of this decade, the rivers received direct input of untreated sugar-cane effluents (Vinhasse) from industrial processing. Over the last few years, however, vinhasse has been applied to the fields together with fertilizers in order to mitigate its direct impact upon the aquatic system. Approximately $30 \%$ of the lower surrounding drainage basin of MMELS is now covered by sugar-cane.

\section{Experimental}

\section{Site description}

The Mundaú-Manguaba estuarine-lagoon system (MMELS) is situated in the State of Alagoas, NE-Brazil (Lat. $9^{\circ} 35^{\prime} \mathrm{S}$ to $9^{\circ} 45^{\prime} \mathrm{S}$ and $35^{\circ} 44^{\prime} \mathrm{W}$ to $35^{\circ} 58^{\prime} \mathrm{W}$ ). It covers a surface area of $81 \mathrm{~km}^{2}$ and has a mean depth of around $2 \mathrm{~m}$. It is composed of three distinct compartments, the Mundaú Lagoon $\left(27 \mathrm{~km}^{2}\right)$, the larger Manguaba Lagoon $\left(42 \mathrm{~km}^{2}\right)$ and the lower narrow mangrove lined channel system $\left(12 \mathrm{~km}^{2}\right)$, which finally connects both lagoons via a single tidal inlet to the Southwest Atlantic Ocean (Figure 1). The watershed has a maximum altitude of $1,000 \mathrm{~m}$ at its head and its climate is governed by a marked spatial and temporal variability. Its upper basin is semi-arid with an annual average precipitation of $800 \mathrm{~mm}$ and the lower basin at the coast is tropical humid, with a precipitation of 1,654 $\mathrm{mm}$ and distinct dry summer (November to March) and wet winter (May to August) conditions. The annual evaporation is $1,109 \mathrm{~mm}$, attaining $106 \mathrm{~mm}$ during the driest and $75 \mathrm{~mm}$ during the wettest month. The annual average fresh water discharge to Mundaú Lagoon by the Mundaú River is $33.5 \mathrm{~m}^{3} \mathrm{~s}^{-1}$, to Manguaba Lagoon by the Paraíba do Meio and the Sumaúma Rivers is 17.6 and $5 \mathrm{~m}^{3} \mathrm{~s}^{-1}$, respectively. Manguaba is generally oligohaline and Mundaú mesohaline, and both are characterized by eutrophic conditions and dominated by phytoplankton. The average annual mean temperature is $25^{\circ} \mathrm{C}$ and the wind regime at the coast is governed by trade winds in summer. ${ }^{18,19}$

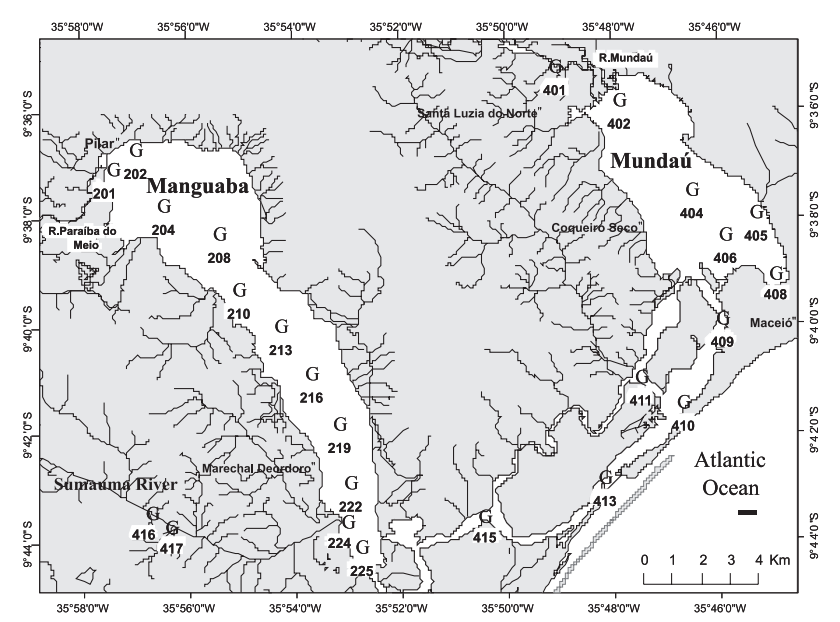

Figure 1. The MMELS study site and distribution of water sampling sites (G). Note: site 227 of the Paraíba do Meio River of Manguaba lagoon is not included in the map.

The narrow coastal plain is surrounded by a plateau of 50 to $100 \mathrm{~m}$ in height, denominated as the late Tertiary Barreiras formation, characterized by iron-rich Latossols. About $30 \%$ of the lower watershed and plateau is covered with sugar-cane monoculture plantations, while the original tropical humid forests now only covers $18 \%$ of the land surface. The sugar-cane practices introduce materials to the lagoon waters by surface runoff, soil erosion, direct river input or via atmospheric transport due to crop burning prior to harvesting. Until the first years of this decade, sugar-cane mills have been active in the basin introducing its effluents directly into the rivers. The direct input of these effluents is now being mitigated by their application on the fields, complementary to fertilizers. In addition, Mundaú Lagoon is also in part affected by domestic effluents from the Maceió City (approximately 900,000 inhabitants). ${ }^{18,19}$

\section{Sampling}

A total of 38 water samples were collected in surface waters for the analyses of triazines in dissolved and suspended particulate matter, of which 19 samples addressed the wet post-harvest season in August 2006 and 19 samples the dry harvest season in February 2008. In addition, standard physico-chemical parameters were measured in situ with an YSI Multiprobe $6600 \mathrm{D}$, including also salinity and Chlorophyll a (i.e. fluorescence). The sampling stations, geographical locations and corresponding conditions of the physicalchemical water properties are shown in Figure 1 and Table 1, respectively.

Samples were collected in $2.5 \mathrm{~L}$ pre-cleaned amber glass bottles and sub-samples of $250 \mathrm{~mL}$ were filtered through glass fiber filters (Whatman GF/C) to retain suspended 
Table 1. Sampling sites and properties of the Mundaú-Manguaba lagoon water during the wet season in August 2006

\begin{tabular}{|c|c|c|c|c|c|c|c|c|c|c|c|}
\hline \multirow{3}{*}{$\begin{array}{l}\text { Sites } \\
\text { Manguaba } \\
201\end{array}$} & \multicolumn{6}{|c|}{ LOCATION } & \multirow{3}{*}{$\begin{array}{c}\text { Temperature } /\left({ }^{\circ} \mathrm{C}\right) \\
25.61\end{array}$} & \multirow{3}{*}{$\begin{array}{c}\text { Salinity/(ppt) } \\
0.13\end{array}$} & \multirow{3}{*}{$\begin{array}{c}\mathrm{pH} \\
7.09\end{array}$} & \multirow{3}{*}{$\begin{array}{l}\begin{array}{l}\text { Chlorophyll a/ } \\
\left(\mu g \mathrm{~L}^{-1}\right)\end{array} \\
7.5\end{array}$} & \multirow{3}{*}{$\frac{\begin{array}{c}\text { Particulates/ } \\
\left(\mathrm{mg} \mathrm{L}^{-1}\right)\end{array}}{35.7}$} \\
\hline & \multicolumn{3}{|c|}{ latitude } & \multicolumn{3}{|c|}{ longitude } & & & & & \\
\hline & 9 & 37 & 2.2 & 35 & 57 & 23.0 & & & & & \\
\hline 204 & 9 & 36 & 56.2 & 35 & 55 & 25.1 & 26.07 & 0.14 & 8.47 & 26.9 & 39.7 \\
\hline 208 & 9 & 38 & 15.3 & 35 & 55 & 24.1 & 26.13 & 0.14 & 8.30 & 30.6 & 43.8 \\
\hline 210 & 9 & 39 & 18.1 & 35 & 55 & 2.6 & 26.11 & 0.14 & 8.19 & 28.7 & 35.6 \\
\hline 216 & 9 & 40 & 52.3 & 35 & 53 & 41.3 & 26.33 & 0.16 & 8.42 & 28.8 & 50.4 \\
\hline 219 & 9 & 41 & 47.6 & 35 & 53 & 10.9 & 26.32 & 0.18 & 8.54 & 26.6 & 41.8 \\
\hline 222 & 9 & 42 & 56.1 & 35 & 52 & 58.4 & 26.65 & 0.16 & 8.81 & 33.6 & 43.5 \\
\hline 224 & 9 & 43 & 36.4 & 35 & 53 & 3.0 & 25.78 & 0.08 & 7.03 & 11.0 & 35.6 \\
\hline 225 & 9 & 44 & 6.9 & 35 & 52 & 46.0 & 26.66 & 0.31 & 7.36 & 15.5 & 33.7 \\
\hline \multicolumn{12}{|l|}{ Mundaú } \\
\hline 401 & 9 & 35 & 12.3 & 35 & 49 & 2.7 & 26.04 & 0.17 & 8.15 & 4.9 & 39.2 \\
\hline 402 & 9 & 35 & 51.1 & 35 & 47 & 52.0 & 26.11 & 0.12 & 7.66 & 4.9 & 27.6 \\
\hline 404 & 9 & 37 & 31.3 & 35 & 46 & 32.0 & 25.92 & 0.82 & 9.36 & 66.1 & 60.1 \\
\hline 405 & 9 & 37 & 56.4 & 35 & 45 & 20.1 & 26.20 & 1.63 & 9.43 & 83.2 & 50.6 \\
\hline 406 & 9 & 38 & 19.7 & 35 & 45 & 52.8 & 25.90 & 3.57 & 9.38 & 52.9 & 37.8 \\
\hline 408 & 9 & 39 & 3.3 & 35 & 44 & 55.9 & 25.94 & 6.73 & 9.12 & 134.1 & 74.7 \\
\hline
\end{tabular}

particulate matter and obtain the filtrates. All filters were weighed for total suspended matter determination.

Surface sediment samples were only collected during the wet season in August 2006. Sampling was performed with a Van Veen type grab at 12 selected stations along the main axis of the lagoons at the same sites as the water samples (Figure 1). The stations of Mundaú Lagoon are indicated in Figure 1 as 401, 402, 404, 405, 406 and 407, and of Manguaba 202, 208, 213, 216, 224, 227. Station 401 corresponds to the fluvial reference of the Mundaú River and station 227 of the Paraíba do Meio River. The samples were kept in aluminum foil boxes, maintained in a freezer and freeze dried. Thereafter, they were homogenized and sieved through $63 \mu \mathrm{m}$, subjected to lyophilization and maintained in a freezer until analysis.

\section{Chemical standards}

The triazine standards (Chemical structures, Figure 2), atrazine (6-chloro- $N$ '-ethyl- $N$-isopropyl-1,3,5-triazine-2,4diamine), simazine (6-chloro- $N, N^{\prime}$-diethyl-1,3,5-triazine2,4-diamine), Deethylatrazine (6-chloro- $N$-isopropyl1,3,5-triazine-2,4-diamine; DEA), Deisopropylatrazine (6-chloro- $N$-ethyl-1,3,5-triazine-2,4-diamine; DIA) and Deethyldeisopropylatrazine (6-chloro-1,3,5-triazine-2,4diamine; DEDIA) were purchased from Dr. Ehrenstorfer (Augsburg, Germany). Deuterated pyrene (pyrene-d $\mathrm{d}_{10} 98 \%$, Cambridge Isotope Laboratories, Andovar, USA) was used as an internal standard. Stock solutions of $1000 \mu \mathrm{g} \mathrm{mL}$ were prepared by weighing $10 \mathrm{mg}$ of each of the solutes and dissolving them in $10 \mathrm{~mL}$ of chromatographic-grade acetonitrile (TediaBrazil, Rio de Janeiro). They were then stored at $-20{ }^{\circ} \mathrm{C}$.



Figure 2. Chemical structures of triazines.

The solvents used for sample processing and analyses (dichloromethane, acetonitrile, acetone, hexane, methanol) were of chromatographic grade from TediaBrazil (Rio de Janeiro, Brazil).

\section{Water samples extraction}

Water samples were extracted using a solid-phase extraction (SPE) Oasis system (Waters, USA). The Oasis SPE cartridges were first conditioned with $6 \mathrm{~mL}$ of dichloromethane followed by $6 \mathrm{~mL}$ of acetonitrile and $6 \mathrm{~mL}$ of distilled water. Water samples $(200 \mathrm{~mL})$ were passed 
through the cartridge under vacuum at a rate of approximately $6 \mathrm{~mL} \mathrm{~min}^{-1}$. Water residues from cartridges were eliminated by $30 \mathrm{~min}$ vacuum. Elution was carried out with $2.5 \mathrm{~mL}$ of acetonitrile-dichloromethane (ACN:DCM; 1:1; v:v) followed by $3.2 \mathrm{~mL}$ of dichloromethane. The solvent was then removed at low temperature $\left(<35^{\circ} \mathrm{C}\right)$ by rotary evaporation. ${ }^{20,21}$

\section{Suspended particulate matter sample extraction}

The filters (four per site, totalling $1 \mathrm{~L}$ of filtered sample) were extracted by ultrasonification in $50 \mathrm{~mL}$ dichloromethane:methanol (DCM:MeOH; 8:2; v:v) for $20 \mathrm{~min}$. The extraction procedure was repeated twice thereafter. The extracts were combined and concentrated by rotary evaporation.

\section{Sediments - pressurized fluid extraction (PFE)}

Extraction was carried out using the ASE 200 (DIONEX, USA). $5 \mathrm{~g}$ of the $<63 \mu \mathrm{m}$ sediment was placed inside an ASE stainless steel $11 \mathrm{~mL}$ cell. The extraction was carried out using dichloromethane:methanol (DCM: $\mathrm{MeOH}$; $8: 2 ; \mathrm{v}: \mathrm{v})$ as solvent. The ASE extraction parameters were: $100{ }^{\circ} \mathrm{C}, 140 \mathrm{bar}, 5 \mathrm{~min}$ of static time, $120 \mathrm{~s}$ of nitrogen purge and 6 extraction cycles.

\section{Sediment and suspended particulate matter clean up procedure}

The extracts were concentrated by rotary evaporation. The concentrated extracts were fractionated by $2.5 \mathrm{~g}$ precleaned silica gel column. The column was eluted first with $10 \mathrm{~mL}$ of hexane, further with hexane:dichloromethane (Hx:DCM; 8:2; v:v) and further elution with $20 \mathrm{~mL}$ dichlorometane:methanol (DCM:MeOH; 8:2; v:v) yielded the triazines.

All the suspended particulate matter extract fractions were concentrated, transferred to an autosampler microvial $(250 \mu \mathrm{L})$, reduced to dryness and blow-downing with $\mathrm{N}_{2}$ and finally made up to a volume of $30 \mu \mathrm{L}$ with pyrene- $\mathrm{d}_{10}$ solution at $0.2 \mathrm{ng} \mu \mathrm{L}^{-1} .{ }^{22,23}$ Blank sample was also evaluated and no interfering peak was observed in the retention time range. For all sediment extract fractions the same procedure was performed but made up to a volume of $400 \mu \mathrm{L}$ with pyrene- $\mathrm{d}_{10}$ solution at $0.2 \mathrm{ng} \mu \mathrm{L}^{-1}$.

\section{Recoveries}

\section{Suspended particulate matter}

The procedure for suspended particulate matter was optimized in our laboratory, based on literatura data. ${ }^{22-24,26,34}$
The triazine elution solvent and extraction solvent mixture were tested and the recovery values presented in Tables 2 and 3. Further, triazine compounds were spiked on four glass fiber filters at four different concentrations $(n=3$, each concentration) to give final concentrations around 10,5,2 and $1 \mu \mathrm{g} \mathrm{L}^{-1}$ for the triazine mixture. The recovery procedure was evaluated and the results are presented in Table 4 .

Table 2. Recovery tests for solvent elution in silica liquid chromatography fortified with $10 \mathrm{ng}$ of each triazine

\begin{tabular}{lccccc}
\hline & \multicolumn{5}{c}{ Recovery / $(\%)$} \\
& Atrazine & Simazine & DEA & DIA & DEDIA \\
\hline Test 1 & 59.5 & 81.5 & 80.5 & 68.5 & 73.5 \\
Test 2 & 42.2 & 44.0 & 34.2 & 31.5 & 12.0 \\
Test 3 & 65.5 & 85.4 & 66.5 & 46.6 & 38.0 \\
Test 4 & 34.1 & 58.3 & 63.2 & 42.0 & 46.9 \\
Test 5 & 41.5 & 54.3 & 58.3 & 46.4 & 59.2 \\
Test 6 & 50.8 & 79.6 & 100.9 & 134.8 & 56.7 \\
\hline
\end{tabular}

Test 1:20mLDCM/MeOH 8:2; Test 2.10mLDCM/MeOH 9:1; Test 3:10mL Hx/Ace 1:1; Test 4: $10 \mathrm{~mL}$ DCM/MeOH 8:2; Test 5: $10 \mathrm{~mL} \mathrm{Hx/Ace} \mathrm{1:1} \mathrm{+}$ $10 \mathrm{~mL}$ DCM/MeOH 8:2;Test 6: $10 \mathrm{~mL} \mathrm{DCM} \mathrm{+} 12 \mathrm{~mL}$ Acetone (Ace).

Table 3. Recovery tests for solvent extraction and elution selection. Fortified filters at $50 \mathrm{ng} \mathrm{L}^{-1}(\mathrm{n}=2)$

\begin{tabular}{lccccc}
\hline \multicolumn{5}{c}{ Recovery / $(\%)$} \\
& Atrazine & Simazine & DEA & DIA & DEDIA \\
\hline Test 7 & 80.0 & 127.9 & 100.1 & 83.3 & 89.9 \\
Test 8 & 53.3 & 73.5 & 75.2 & 61.1 & 53.8 \\
Test 9 & 73.8 & 66.5 & 66.1 & 70.8 & 54.1 \\
Test 10 & 84.1 & 71.2 & 74.1 & 86.9 & 56.6 \\
\hline
\end{tabular}

Test 7: Extraction and LC with DCM/MeOH (8:2); Test 8: Extraction and LC with Hx/Ace (1:1) + DCM/MeOH (8:2);Test 9: Extraction with $\mathrm{Hx} /$ Ace $(8: 2)$ and LC with DCM/MeOH (8:2); Test 10: Extraction with Hx/Ace (8:2) and LC with DCM+Ace.

Table 4. Recovery experiments $(n=3)$, relative standard deviation (RSD), LOD and LOQ for fortified filter samples submitted to extraction and liquid chromatography (LC) with dicloromethane:methanol (8:2 / v:v). Concentrations in $\mathrm{ng} \mathrm{L}^{-1}$

\begin{tabular}{|c|c|c|c|c|c|}
\hline \multirow[b]{2}{*}{ Concentration } & \multicolumn{5}{|c|}{ Recovery / (\%) } \\
\hline & Atrazine & Simazine & DEA & DIA & DEDIA \\
\hline 10 & 72 & 73 & 72 & 53 & 45 \\
\hline RSD & 25 & 20 & 27 & 8 & 19 \\
\hline 5 & 90 & 75 & 68 & 58 & 49 \\
\hline RSD & 18 & 8 & 9 & 7 & 25 \\
\hline 2 & 86 & 90 & 87 & 84 & 88 \\
\hline RSD & 20 & 17 & 22 & 3.3 & 0.4 \\
\hline 1 & 107 & 123 & 121 & 102 & 92 \\
\hline RSD & 4.8 & 7.3 & 9.2 & 17 & 7.6 \\
\hline LOD & 0.2 & 0.2 & 0.2 & 0.3 & 0.3 \\
\hline LOQ & 0.7 & 0.7 & 0.6 & 0.9 & 1.0 \\
\hline
\end{tabular}




\section{Sediments}

Recoveries of the compounds under study were evaluated. The sediment samples were spiked with the target solution at concentrations of 10,20 and $50 \mathrm{ng} \mathrm{g}^{-1}$ and extracted in duplicate as described above.

\section{Quantification}

External standard calibration curves were used for quantification of the triazine fractions in addition to the pyrene- $\mathrm{d}_{10}$ (at $0.2 \mathrm{ng} \mu \mathrm{L}^{-1}$ ) as internal standard. Calibration graphs for SIM mode were plotted using six to eight points

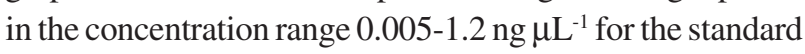
solution mixture.

\section{Limits of detection and quantification}

The limits of detection (LODs) were calculated by using a signal-to-noise ratio of 3 (the ratio between the peak intensity under SIM conditions and the intensity of the noise was used), and was calculated from recovery experiments at the lowest fortification level. ${ }^{20}$

The limits of quantification (LOQ) was considered as three times the LOD values for suspended particulate matter and using a signal-to-noise ratio of 5 for sediment experimental procedure, but always using the lowest fortification level.

For dissolved compounds, LOD was considered from the values obtained for atrazine and simazine of previous work, following the same extraction procedure, being 8 and $10 \mathrm{ng} \mathrm{L}^{-1}$, respectively. ${ }^{20,21}$ Thus a routine limit of quantification was stipulated as $10 \mathrm{ng} \mathrm{L}^{-1}$, since in the present study the final volume was $30 \mu \mathrm{L}$ instead of $100 \mu \mathrm{L}$.

\section{$G C-M S$ conditions}

GC-MS analyses were performed in an Agilent Technologies (Palo Alto, CA, USA) gas chromatograph (GC) model 6890 equipped with a $7673 \mathrm{HP}$ auto sampler coupled with a quadrupole mass spectrometer (MS), Agilent (MS 5973 Network). The carrier gas was Helium at $1.2 \mathrm{~mL} \mathrm{~min}^{-1}$, in constant flow mode. A DB-5 capillary column (5\% phenyl, $95 \%$ methylsiloxane, $30 \mathrm{~m}, 0.25 \mathrm{~mm}$ i.d., film thickness $0.25 \mu \mathrm{m}$ ) was used. Injector temperature was $290{ }^{\circ} \mathrm{C}$. The GC temperature programming rates corresponded to the initial column oven temperature at $50^{\circ} \mathrm{C}$ (held $1 \mathrm{~min}$ ) and subsequent rises to $150^{\circ} \mathrm{C}$ at $25^{\circ} \mathrm{C} \mathrm{min}^{-1}$ (held $4 \mathrm{~min}$ ), $200^{\circ} \mathrm{C}$ at $4{ }^{\circ} \mathrm{C} \mathrm{min}{ }^{-1}$ and to $310^{\circ} \mathrm{C}$ at $30^{\circ} \mathrm{C} \mathrm{min}^{-1}$ (held $5 \mathrm{~min}$ ). The injection volume for suspended particulate and dissolved matter was $3 \mu \mathrm{L}$ and for sediment samples $1 \mu \mathrm{L}$, at splitless mode. Mass spectrometer operating conditions were: ion source temperature $230{ }^{\circ} \mathrm{C}$; transfer line was at $300{ }^{\circ} \mathrm{C}$; quadrupole temperature of $150{ }^{\circ} \mathrm{C}$; and the ionization voltage of $70 \mathrm{eV}$. Samples were analyzed in SIM mode. Before analysis, triazine standard solutions were run to check column performance, peak height and resolution. With each set of samples analyzed, a solvent blank and a standard mixture were run in sequence to check for contamination, peak identification and quantification.

\section{Results and Discussion}

\section{Evaluation of the analytical method}

First of all, the analytical procedure for suspended particulate matter was evaluated using authentic standard solution. The elution solvents in the liquid chromatography were selected from data observed in the literature. ${ }^{24,26,34}$ The standard solution was applied at the top of the silica column, at $10 \mathrm{ng}$ for each compound. The best result was obtained with dichloromethane:methanol (8:2/ v:v) (Table 2). The recovery experiments for extraction solvent selection together with the elution solvent were carried out with fortified filters at $50 \mathrm{ng} \mathrm{L^{-1 }}$. These results are presented in Table 3. The same procedure was repeated with lower triazine concentration values, near the limits of quantification already reported in the previous work of Gfrerer et al. ${ }^{24}$ The authors presented LOQ at 1, 5, 4 and $4 \mathrm{ng} \mathrm{L}^{-1}$ for atrazine, simazine, deethylatrazine and deisopropylatrazine, respectively. Thus, fortified filters with triazines at 10, 5, 2 and $1 \mathrm{ng} \mathrm{L}^{-1}$ were processed and the results presented in Table 4. It can be observed that the obtained LOD for all triazines were around 0.2-0.3 $\mathrm{ng} \mathrm{L}^{-1}$ and the limits of quantification (LOQ), considering three times the LOD values, were found at 0.6 to $1.0 \mathrm{ng} \mathrm{L}^{-1}$. These data are better than those previously described, ${ }^{24}$ with excellent recoveries between 72 and $123 \%$, mainly for 1 and $2 \mathrm{ng} \mathrm{L}^{-1}$ concentrations and relative standard deviations of 4.2 to $22 \%$. Standard deviations were around $10 \%$, but always below $30 \%$, following the US Environmental Protection Agency (EPA) method that stipulates acceptable recovery values in the range of 70 up to $130 \%$ with a maximum relative standard deviation of $30 \%$ each. ${ }^{25}$ The methods' performance was evaluated following standard quality parameters such as response linearity, accuracy (recovery), precision, detection limit and quantification.

The analytical procedure for the sediments was also evaluated to provide credibility to the results and later applied to samples. Selected samples were spiked with the standard mixture solution at three different concentration levels. The applied method was based on obtained results for suspended particulate matter and literature data. ${ }^{26}$ The 
results are presented in Table 5 and exhibit good recoveries, standard deviations from good to acceptable, mainly for atrazine and simazine, and LODs from 0.6 to $1.2 \mathrm{ng} \mathrm{g}^{-1}$. The composite mass chromatogram $\mathrm{m} / \mathrm{z} 200,201$ and 212 , for atrazine, simazine and pyrene- $\mathrm{d}_{10}$, respectively, illustrated in Figure 3 exhibits the good resolution and peak identification for all the three concentrations analyzed. For comparison, a study from Portugal with sediment samples of low total organic carbon content (1 g dry mass), were spiked at $15 \mathrm{ng} \mathrm{g}^{-1}$, extracted with ASE system and recoveries for atrazine and simazine were 108 and $111 \%$ and standard deviations of 13 and 9.7 , respectively. ${ }^{26}$

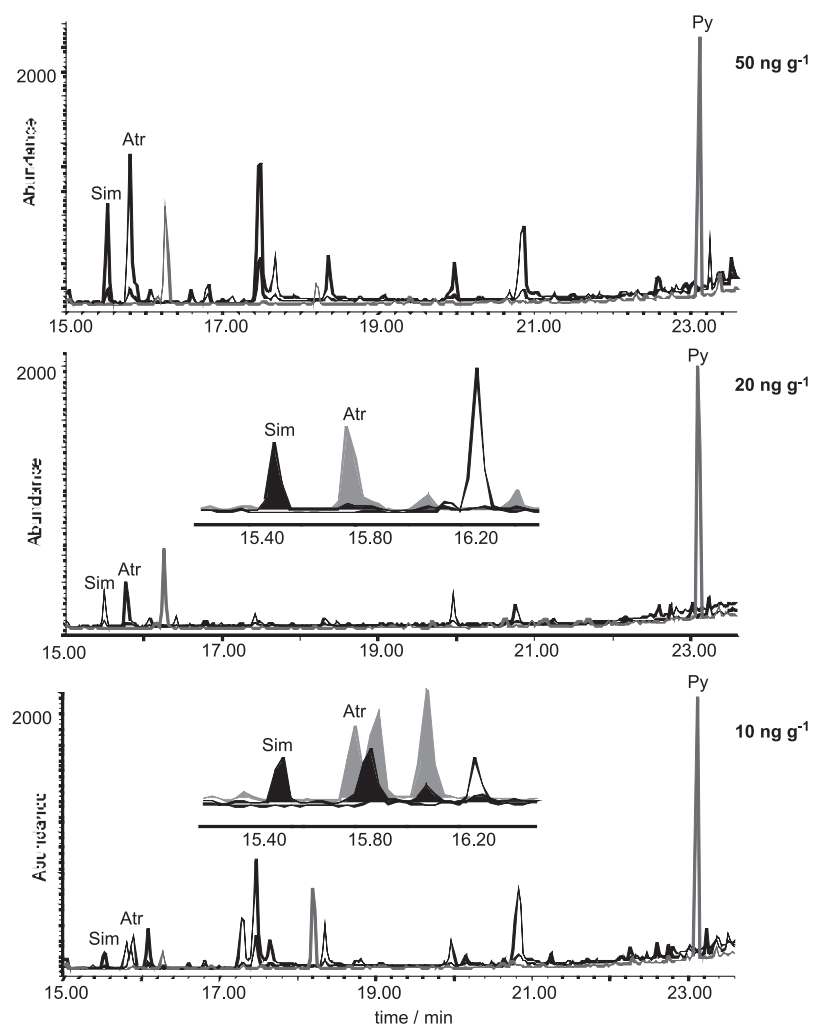

Figure 3. Composite mass chromatogram $\mathrm{m} / \mathrm{z}, 200,201,212$ for atrazine, simazine and pyrene- $\mathrm{d}_{10}$, respectively, at 50, 20 and $10 \mathrm{ng} \mathrm{g}^{-1}$.

Table 5. Recovery ( $\%, \mathrm{n}=2$ ), relative standard deviation (RSD), LOD and LOQ for fortified sediment samples with 50, 20 and $10 \mathrm{ng} \mathrm{g}^{-1}$ of each triazine

\begin{tabular}{lcccc}
\hline & \multicolumn{4}{c}{ Recovery / $(\%)$} \\
Concentration & Atrazine & Simazine & DEA & DIA \\
\hline 50 & 133 & 109 & 73 & 73 \\
RSD & 6.8 & 2.1 & 10.6 & 11.2 \\
20 & 112 & 83 & 51 & 58 \\
RSD & 11.8 & 9.7 & 41.5 & 27.8 \\
10 & 87 & 103 & 68 & 95 \\
RSD & 13.2 & 2.1 & 32.4 & 34 \\
LOD & 0.6 & 1.0 & 0.9 & 1.2 \\
LOQ & 0.9 & 1.6 & 1.4 & 2.0 \\
\hline
\end{tabular}

\section{Monitoring study of target analytes}

The analyses were carried out by GC-MS using selected ion monitoring. Each triazine herbicide was identified with its diagnostic ion (the most intense one) and later, confirmed with the second and third characteristic ions, besides the retention time. Also, the ratio between two ions (mainly the two most intense ones) must be maintained in the same range as the authentic standard at the same concentration level, with acceptable variations around 10-20\%. Table 6 depicts the compound names, retention time and diagnostic ions.

Table 6. Compound names, molecular weight, diagnostic and characteristic ions, and retention times for triazine herbicides and internal standard

\begin{tabular}{lcccc}
\hline Compound & MW & $\begin{array}{c}\text { Diagnostic } \\
\text { ion } /(\mathrm{m} / \mathrm{z})\end{array}$ & $\begin{array}{c}\text { Characteristic } \\
\text { ions } /(\mathrm{m} / \mathrm{z})\end{array}$ & $\mathrm{t}_{\mathrm{R}} /(\mathrm{min})$ \\
\hline Atrazine & 215 & 200 & 215,173 & 15.55 \\
Simazine & 201 & 201 & 186,173 & 15.27 \\
$\begin{array}{l}\text { Deethyl } \\
\text { atrazine }\end{array}$ & 187 & 172 & 187,145 & 13.35 \\
$\begin{array}{l}\text { Deisopropyl } \\
\text { atrazine }\end{array}$ & 173 & 173 & 158,145 & 13.02 \\
$\begin{array}{l}\text { Deethyldeisopropyl } \\
\text { atrazine }\end{array}$ & 145 & 145 & 110,147 & 10.76 \\
Pyrene-D & 212 & 212 & 106 & 22.98 \\
\hline
\end{tabular}

Of the thirty-eight suspended particulate matter samples analyzed, only atrazine was detected at four sites, namely 404, 405 and 408 in Mundaú and 210 in Manguaba, during the rainy season. Atrazine values were rather low with 3.1, 2.7 and $1.6 \mathrm{ng} \mathrm{L}^{-1}$ at sites 404, 408 and 405, respectively; while the Manguaba site exhibited $0.7 \mathrm{ng} \mathrm{L}^{-1}$ (or 64.2, 36.2 and $31.3 \mathrm{ng} \mathrm{g}^{-1}$ for Mundaú and $25.6 \mathrm{ng} \mathrm{g}^{-1}$ for Manguaba, respectively). The $m / z, 200$ mass chromatograms for atrazine in detected samples and for authentic standard are presented in Figure 4 for data confirmation. The atrazine concentrations in Mundaú lagoon were found in its most confined area and also close to a point source of effluents from Maceió City. In addition, these values match with higher suspended particulate matter values of these sites, 50.6 to $74.7 \mathrm{mg} \mathrm{L}^{-1}$ (see Table 1) during the wet season, in contrast to the lower concentrations of the dry season, which ranged from 0.7 to $23.5 \mathrm{mg} \mathrm{L}^{-1}$, devoid of triazines. The rainy season with its larger potential of soil erosion must have introduced higher suspended particulate matter concentrations and associated atrazine to the water column of the lagoons. Gfrerer et al..$^{24}$ also detected very low triazine concentrations concomitant to low amounts of suspended solids in surface waters. Furthermore, no triazines were detected in the dissolved fraction (above $10 \mathrm{ng} \mathrm{L}^{-1}$, considered LOQ levels), including during the wet 
season with its maximum wash-out potential of materials from the watershed. Similar results were also obtained by Dammshäuser ${ }^{27}$ who analyzed atrazine in the dissolved water fractions in Manguaba lagoon at the beginning of the harvesting period in October 2007. The LOQ values considered in this study for the dissolved fraction were lower than the maximum admissible concentration established by the European Union for an individual compound in drinking water $\left(0.1 \mu \mathrm{g} \mathrm{\textrm {L } ^ { - 1 }}\right)$.

(A)

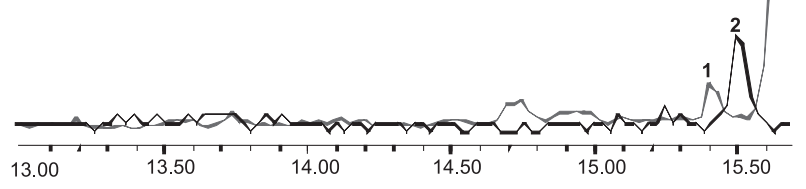

(B)
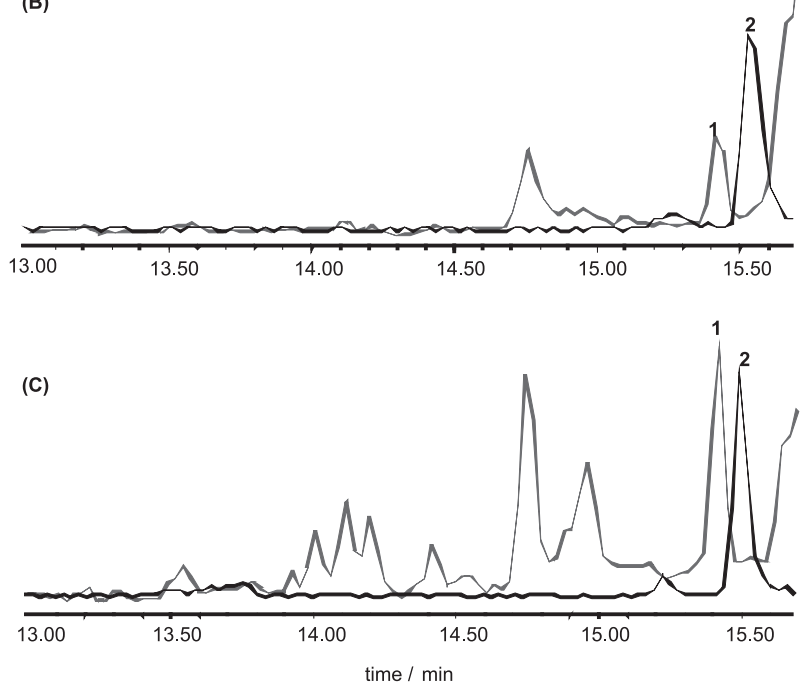

Figure 4. Mass chromatograms $m / z, 200$ for atrazine standard (2) and (A) Manguaba, sample 210 (1); (B) Mundaú, sample 404 (1); (C) Mundaú, sample 408 (1).

In general, the low concentrations of atrazine detected at the four sites $\left(0.7-3.1 \mathrm{ng} \mathrm{L}^{-1}\right)$ lied far below the stipulated limits by USEPA or European Community for drinking or surface waters and in the same range as previously observed in Chinese River ${ }^{24}$ samples.

Concomitant to the majority of the water samples, triazines were also not detected (or are < LOD) in the surface sediments, in spite of the good experimental recoveries and limits of detection varying from 0.6 to $1.2 \mathrm{ng} \mathrm{g}^{-1}$ and considering the sedimentary matrix with high organic carbon contents of 2.4-5.0\%. It is assumed that atrazine already present in very low concentrations in suspended particulate matter are subject to further degradation in the water and at the sediment-water interface after particle deposition. It is a well known fact that eutrophic systems with nepheloyd layers at the sedimentwater interface, including MMELS and other tropical Brazilian lagoons, ${ }^{28-30}$ are highly efficient sites of organic matter reworking and degradation. The high Chlorophyll a contents depicted in Table 1 imply the presence of substantial primary production by phytoplankton and, as such, also total system metabolism generally involving high microbial degradation rates. Similar Chlorophyll a contents are found in the eutrophic coastal lagoons of Rio de Janeiro, subject to high system metabolism and degradation rates of organic matter. ${ }^{29}$

Until now, few studies had reported on the occurrence of chlorotriazines in particulate matter and sediments as it is assumed that these pesticides are mainly present in the dissolved phase based on their physico-chemical properties. Triazines are relatively polar compounds $\left(\log \mathrm{K}_{\mathrm{ow}}\right.$ values between 2 and 3) and have a moderate to good water solubility (6-30 $\mathrm{m} \mathrm{L}^{-1}$ ) depending on the temperature, $\mathrm{pH}$ and aqueous chemistry. ${ }^{31}$ Temperatures during the present study of the lagoon compartments lied in the range between 25 and $29{ }^{\circ} \mathrm{C}$ and $\mathrm{pH}$ varied from around 7.0 to 9.4, depending on the location of the sampling station and season. Lowest $\mathrm{pH}$ values were always recorded at the river mouths at the upper sections of the lagoons (Table 1). ${ }^{32}$ However, as suggested by Smalling and Aelion, ${ }^{33}$ sorption can increase due to the high organic carbon and clay content of estuarine sediments and suspended solids. Also, suspended matter content is highly variable due to the variations in (freshwater) river inputs, rainfall, dredging, shipping, and mixing and sedimentation processes. ${ }^{34}$ All of these processes must have been operating along the estuarine gradient of MMELS, but atrazine was only detected with higher concentrations in the suspended particulate matter.

Laabs et al. ${ }^{4}$ monitored 29 pesticides and 3 metabolites in surface water and sediment in Pantanal Basin, Mato Grosso State, Brazil. Sediment samples spiked at $100 \mathrm{ng} \mathrm{g}^{-1}$ gave recoveries for atrazine and simazine of 97 and $95 \%$ and limits of quantification of $0.4 \mathrm{ng} \mathrm{g}^{-1}$. However, they used $25 \mathrm{~g}$ of sediment dry mass, instead of the lower masses of this study which also yielded good recoveries. Despite of the larger sediment mass used, they only detected simazine and at $0.5 \mathrm{ng} \mathrm{g}^{-1}$.

In a one-year monitoring program of two Eastern Chinese River systems, sediments were extracted with fluidized-bed extraction (FBE) and the recoveries obtained were between 83.3 to $99.8 \%$ at limits of quantification of $0.1,0.4,0.5 \mathrm{ng} \mathrm{g}^{-1}$ for triazines. Atrazine was detected at 
0.5-2.8 $\mathrm{ng} \mathrm{g}^{-1}$. The triazine concentrations in sediments were low, but concomitant to the low organic carbon concentrations (between $0.02 \%$ and $1.17 \%$ ). ${ }^{24}$

The occurrence of atrazine, simazine and terbutylazine in water, suspended matter and sediments were studied in the Scheldt estuary (Belgium-The Netherlands). ${ }^{35}$ Atrazine was found at much higher concentrations, varying from 10 to $736 \mathrm{ng} \mathrm{L}^{-1}$ in water and from 5 up to $10 \mathrm{ng} \mathrm{g}^{-1}$ in suspended matter. Simazine and terbutylazine were detected at lower concentrations. Traces of the target pesticides were also detected in sediments, but these were below the limit of quantification, considered at $5 \mathrm{ng} \mathrm{g}^{-1}$. Yet, atrazine was only detected in 2 of the 45 suspended matter samples collected at concentrations of 6.6 and $9.9 \mathrm{ng} \mathrm{g}^{-1} \mathrm{~d}$.w. Also simazine was only detected in two samples at concentrations of 5 and $8.4 \mathrm{ng} \mathrm{g}^{-1}$.

In river sediments from Portugal, 28 priority pesticides were quantified, with atrazine and simazine included, and simazine was detected in three sediment samples at 7.0, 8.6 and $15.7 \mathrm{ng} \mathrm{g}^{-1}$ concentration levels. These values were also higher when compared to those detected in some tropical sites. ${ }^{26}$

It seems that, many triazine studies performed in aquatic systems with agricultural activities, different climates, environmental conditions and substrate composition, all backed by good experimental recoveries, in general yielded low to undetectable concentrations of these compounds, both in the water and the surface sediments, except for some cases directly subject to high loads of triazines. Furthermore, manifold physico-chemical processes, water turn over times and also the degree of metabolism of the systems, affect the residence times and accumulation of these compounds, and as such the potential of their degradation. MMELS, due to its large degree of enclosure and high residence times of water, corresponds to an organic-rich system with a high metabolism driven by phytoplankton and an efficient retainer of alochthonous and autochthonous matter. ${ }^{18}$ These conditions indicate that the system harbors a high potential for material degradation and, likely also, triazines.

\section{Conclusions}

The recoveries for the five triazines evaluated in suspended particulate matter were excellent, from 72 to $123 \%(n=3)$.

The LOQs obtained for the triazines in suspended particulate matter were lower than the previous work, at $<1 \mathrm{ng} \mathrm{L}^{-1}$. For sediment samples, the recoveries were in the range 51 to $133 \%(\mathrm{n}=2)$. The LODs were $0.6-1.2 \mathrm{ng} \mathrm{g}^{-1}$.

Only low concentrations of atrazine were detected in samples from the Mundaú-Manguaba system, at three sites from the Mundaú and one from the Manguaba lagoons during the rainy season. This was coupled to the higher concentrations of suspended particulate matter washed-out from the watershed. Triazines were neither detected in their dissolved fraction nor in the surface sediments of MMELS.

Although Atrazine is still being applied under restricted conditions in the sugar-cane practices of the State of Alagoas, it seems that a large fraction is likely being retained and metabolized in the soils. Furthermore, the high metabolism of MMELS and organic carbon content of organic matter in the sediments, also suggest that triazines are probably efficiently degraded in the system.

\section{Acknowledgments}

This work was supported by CNPq, the Brazilian National Research Council, (Project POLCAMAR, Proc. No. 590002/2005-8 ASCIN/CNPq). We also would like to thank Dr. Paulo P. R. Medeiros of the Federal University of Alagoas (UFAL) for support in the laboratory and field work. The authors also acknowledge the CNPq for fellowships. B. Knoppers is a CNPq Senior Research Fellow (Proc. No. 306157/2007-1).

\section{References}

1. Zamperlini, G. C. M.; Santiago-Silva, M.; Vilegas, W.; J. Chromatogr. A 2000, 889, 281.

2. http://www.unica.com.br, accessed in March 2009. In Portuguese.

3. Racke, K. D.; Skidmore, M. W.; Hamilton, D. J.; Unsworth, J. B.; Miyamoto, J.; Cohen, S. Z.; Pure Appl. Chem. 1997, 69, 1349.

4. Laabs, V.; Amelung, W.; Pinto, A. A.; Wantzen, M.; Silva, C. J.; Zech, W.; J. Environ. Qual. 2002, 31, 1636.

5. Miranda, K.; Cunha, M. L. F.; Dores, E. F. G. C.; Calheiros, D. F.; J. Environ. Sci. Health, Part B 2008, 43, 717.

6. Dores, E. F. G. C.; Navickiene, S.; Cunha, M. L. F.; Carbo, L.; Ribeiro, M. L.; De-Lamonica-Freire, E. M.; J. Braz. Chem. Soc. 2006, 17, 866 .

7. Carbo, L.; Souza, V.; Dores, E. F. G. C.; Ribeiro, M. L.; J. Braz. Chem. Soc. 2008, 19, 1111.

8. Rissato, S. R.; Libânio, M.; Giafferis, G. P.; Gerenutti, M.; Quim. Nova, 2004, 27, 739.

9. Dean, J. R.; Wade, G.; Barnabas, I. J.; J. Chromatogr. A 1996, 733, 295.

10. Loos, R.; Niessner, R.; J. Chromatogr. A 1999, 835, 217.

11. Hayes, T.; Haston, K.; Tsui, M.; Hoang, A.; Haeffele, C.; Vonk, A.; Environ. Health Perspect. 2003, 111, 658.

12. US-EPA. Decision documents for atrazine, United States Environmental Protection Agency. 2006. 
13. US-EPA. Registration eligibility decision for simazine, United States Environmental Protection Agency. 2006.

14. Commission Decision 2004/248/EC of 10 March 2004 concerning the non-inclusion of atrazine in Annex I to Council Directive 91/414/EEC and the withdrawal of authorisations for plant protection products containing this active substance. OJL, 78, 16.03.2004, p. 53-55.

15. Commission Decision 2004/247/EC of 10 March 2004 concerning the non-inclusion of simazine in Annex I to Council Directive 91/414/EEC and the withdrawal of authorisations for plant protection products containing this active substance. OJL, 78, 16.3.2004, p. 50-52.

16. Proposal for a Directive of the European Parliament and of the Council on environmental quality standards in the field of water policy and Amending Directive 2000/60/EC. COM (2006) 397 final.

17. http://www.cnpma.embrapa.br/herbicidas, accessed in February 2009. In Portuguese.

18. Oliveira, A. M.; Kjerfve, B.; Estuar. Coast. Shelf Sci. 1993, 37, 575.

19. ANA/CELMM. Plano de Ações e Gestão Integrada do Complexo Estuarino-Lagunar Mundaú-Manguaba CELMM. Agência Nacional de Águas, Brazil, 2006. In Portuguese.

20. Azevedo, D. A.; Lacorte, S.; Vinhas, T.; Viana, P.; Barceló, D.; J. Chromatogr. A 2000, 879, 13.

21. Azevedo, D. A.; Gerchon, E.; Reis, E. O.; J. Braz. Chem. Soc. 2004, 15, 292.

22. Silva, T. F.; Azevedo, D. A.; Aquino Neto, F. R.; J. Braz. Chem. Soc. 2007, 18, 628.

23. Silva, T. F.; Azevedo, D. A.; Aquino Neto, F. R.; Environ. Forensics 2007, 8, 257.
24. Gfrerer, M.; Martens, D.; Gawlik, B. M.; Wenzl, T.; Zhang, A.; Quan, X.; Sun, C.; Chen, J.; Platzer, B.; Lankmayr, E.; Kettrup, A.; Chemosphere 2002, 47, 455.

25. Barceló, D.; J. Chromatogr. 1993, 643, 117.

26. Villaverde, J.; Hildebrandt, A.; Martinez, E.; Lacorte, S.; Morillo, E.; Maqueda, C.; Viana, P.; Barceló, D.; Sci. Total Environ. 2008, 390, 507.

27. Dammshäuser, A.; Diploma (MSc) Thesis, University of Rostock, Germany, 2008.

28. Knoppers, B.; Kjerfve, B. In Estuaries of South America; Perillo, G. M. E.; Piccolo, M. C.; Piño-Quivera, M., eds., Springer Verlag: Berlin, 1999.

29. Knoppers, B.; Carmouze, J. P.; Moreira-Turcq, P. F. In Environmental Geochemistry of Coastal Lagoon Systems of Rio de Janeiro, Brazil; Knoppers, B. A.; Bidone, E. D.; Abrão, J. J., eds.; Série Geoquímica Ambiental, Editora UFF/FINEP: Rio de Janeiro, Brasil, 1999, vol. 6.

30. Knoppers, B.; Machado, E. C.; Brandini, N.; Landim de Souza, W. F. In Environmental Geochemistry in Tropical and Subtropical Environments; Lacerda, L. D.; Dantelli, R. E.; Duursma, E. K.; Abraão, J. J., eds., Springer Verlag: Berlin, 2005, ch. 19.

31. Steen, R. J. C. A.; Van Hattum, B.; Brinkmak, U. A. Th.; J. Environ. Monit. 2000, 2, 597.

32. Nazário, M. G.; MSc Dissertation, Universidade Federal Fluminense, Brazil, 2008.

33. Smalling, K. L.; Aelion, C. M.; Chemosphere 2006, 62, 188.

34. Bowman, J. C.; Zhou, J. L.; Readman, J. W.; Mar. Chem. 2002, 77, 263.

35. Noppe, H.; Ghekiere, A.; Verslycke, T.; Wulf, E. D.; Verheyden, K.; Monteyne, E.; Polfliet, K.; Caeter, P.; Janssen, C. R.; Brabander, H. F. D.; Environ. Pollut. 2007, 147, 668.

Received: August 6, 2009 Web Release Date: March 15, 2010 